\title{
The Effect of Repeated Whole-Body Cryostimulation on the HSP-70 and Lipid Metabolisms in Healthy Subjects
}

\author{
A. LUBKOWSKA ${ }^{1}$, I. BRYCZKOWSKA ${ }^{1}$, Z. SZYGULA $^{2}$, C. GIEMZA $^{3}$, A. SKRZEK $^{3}$, \\ I. ROTTER ${ }^{4}$, G. LOMBARDI ${ }^{5}$, G. BANFI ${ }^{5,6}$
}

${ }^{1}$ Department of Functional Diagnostics and Physical Medicine, Faculty of Health Sciences, Pomeranian Medical University in Szczecin, Szczecin, Poland, ${ }^{2}$ Department of Physiotherapy, State University of Applied Sciences in Nowy Sacz, Nowy Sacz, Poland, ${ }^{3}$ Faculty of Physiotherapy, University School of Physical Education in Wrocław, Wroclaw, Poland, ${ }^{4}$ Department of Medical Rehabilitation, Pomeranian Medical University in Szczecin, Poland, ${ }^{5}$ Laboratory of Experimental Biochemistry and Molecular Biology, IRCCS Instituto Ortopedico Galeazzi, Milano, Italy, ${ }^{6}$ Vita-Salute San Raffaele University, Milano, Italy

Received June 3, 2018

Accepted December 11, 2018

Epub Ahead of Print March 22, 2019

\section{Summary}

The aim of this study was to evaluate the effects of exposure to 30 daily whole body cryostimulation (WBC) on lipid metabolic parameters and serum HSP-70 concentration. The study involved 45 volunteers, homogeneous in terms of diet and daily physical activity. Blood samples were collected before and after the $10^{\text {th }}$, the $20^{\text {th }}$, and the $30^{\text {th }}$ session and one month after the intervention. Total cholesterol, HDL, TG concentrations and Apolipoprotein A-I, ApoB and HSP-70 protein levels were determined in serum. Additionally, the LI (Lipid Index) and the LDL level were calculated. During exposure, positive changes in the lipid profile that included a decrease in the TCh, initiated after the $20^{\text {th }}$ WBC session with a simultaneous decrease in TG and LDL levels, and an increase in the HDL concentration were observed. These changes were accompanied by a downward trend in the $A p o B$ concentration and a decrease in the ApoB:ApoA-I ratio after 30 sessions. The nature of these changes persisted for a month after the exposure. The obtained results indicate metabolic benefits that result from prolonged exposure to cryogenic temperatures, confirming the postulate of using WBC in the regulation of lipid metabolism and the prevention of cardiovascular diseases.

\section{Key words}

Cryostimulation • Lipid metabolisms • Heat shock protein • Dyslipidemia

\section{Corresponding author}

A. Lubkowska, Department of Functional Diagnostics and Physical Medicine, Faculty of Health Sciences, Pomeranian Medical University in Szczecin, Żołnierska 54, 71-210 Szczecin, Poland. E-mail: annalubkowska@gmail.com

\section{Introduction}

The essence of whole-body cryostimulation (WBC) interventions thermal stimulation as well as causing the body to transfer as much heat as possible to the surroundings in the shortest possible time (1-3 min) and inducing in the body a physiological thermoregulation response that is the basis for lasting therapeutic effects. A single WBC intervention lasts 1 to maximum $3 \mathrm{~min}$ and is generally done at a temperature in the range of -100 to $-160{ }^{\circ} \mathrm{C}$. Therapeutic application of the appropriate dose of cold, using the effects of intensified physiological thermoregulation mechanisms and naturally and constantly active physical mechanisms of heat transport, induces the effect of stimulation being associated with the hyperemic effect (Castellani and Andrew 2016, Cholewka et al. 2011, Chudecka et al. 2014, Dębiec-Bąk et al. 2013). Previous human studies have focused on the cryostimulation induced changes in basal hormone levels (Banfi et al. 2010, Banfi et al. 
2009a, Smolander et al. 2009), neuromuscular parameters (Hausswirth et al. 2013, Woźniak et al. 2007), anti-inflammatory and analgesic response (Banfi et al. 2009a, Lubkowska and Szyguła 2010a, Pournot et al. 2011), immune system modulation (Banfi et al. 2010), assessment of cardiovascular hemodynamic parameters (Lubkowska and Szyguła 2010a, Lubkowska and Suska 2011, Zalewski et al. 2014) and hematological parameters (Banfi et al. 2009b, Szygula et al. 2014). It has been documented that cryogenic temperatures, during WBC intervention, induce transitory oxidative stress in humans (Lubkowska et al. 2009, Lubkowska et al. 2008, Lubkowska et al. 2010b). The evolutionary conserved family of heat shock proteins (HSPs) is responsible for protecting cells against different types of stress, including oxidative stress. Therefore, it seems interesting whether cryostimulation could be a factor inducing activation of the heat shock response, and whether repeated exposure to cold could lead to changes in heat shock protein (HSP) levels. The importance of these proteins for resistance to heat stress is well documented (Jäättelä 1999, Kregel 2002), but little is known about the cold shock responses. Although the levels of HSPs can be readily measured in blood serum and HSP-70 is one of the more extensively studied HSPs, the levels of HSP-70 have not been studied before in humans subjected to WBC. The direct effect of cold on the body during $\mathrm{WBC}$ is a regionally varied reduction of surface body temperature even by a few ${ }^{\circ} \mathrm{C}$ (Cholewka et al. 2011, Chudecka et al. 2014), without significant changes in core body temperature (Castellani and Andrew 2016, Dębiec-Bąk et al. 2013, Selfe et al. 2014). Limitation of the heat loss with a simultaneous increase in its production due to intensified activity of metabolism is a basic defense response of the body when exposed to cold (Brojek and Warzocha 2006). Adipose tissue is the major storage depot of lipids, which are being used, in the initial stage of increased metabolism as a source of energy (Brojek and Warzocha 2006). The adipose tissue serves as a store of readily mobilized substrate, free fatty acids (FFA) for thermogenesis in other tissues during cold-exposure, principally for shivering thermogenesis in skeletal muscles. Lipid metabolism, including lipogenesis, lipolysis and fatty acid oxidation, is under tight control of the sympathetic nervous system (SNS) and adipose-derived hormones (Spiegelman and Flier 2001). Cooling of the skin during cryostimulation intervention activates cold-sensitive lowand high-threshold receptors subserved by $\mathrm{A} \delta$ and $\mathrm{C}$ fibers with selective autonomic responses (Kregel et al.
1992). Another possible mechanism is represented by the induction of irisin in skeletal muscles, a myokine enhancing the thermogenic capacity, which is induced by cold (Dulian et al. 2015). It seems that changes in lipid metabolism occurred during repeated exposure to cryogenic temperatures used systematically can affect the concentration of lipid fractions in blood serum and, consequently, induce changes of an adaptive nature, the consequences of which could be significant in the prevention of metabolic syndrome or diabetes. To date, only a limited number of studies investigated the potential impact of WBC on lipid profile. The results published so far have referred to research based on animal models, i.e. rats exposed to cryogenic temperatures (Kepinska et al. 2017, Skrzep-Poloczek et al. 2002). Our previous findings refer to changes in the concentration of cholesterol fractions in subjects following 5, 10 and $15 \mathrm{WBC}$ intervention sessions (Lubkowska et al. 2010c). It was observed that significant positive changes began to appear only after 15 daily intervention sessions, which prompted us to continue this research on a larger group of subjects, with an increased number of sessions in a series and increased range of analyzed parameters. Since the aim of this study was to examine the effects of 30 daily cryostimulation sessions on potential adaptive changes in lipid profiles, the serum level of apoliprotein A (ApoA) and B (ApoB), lipid index (LI) and possible correlation with HSP70 protein levels were determined.

\section{Methods}

\section{Subjects}

Forty-five male volunteers took part in the study, all subjects were students of the General Tadeusz Kościuszko Military Academy of Land Forces. According to the Declaration of Helsinki, each participant signed a written informed consent before taking part in the study. The study was also approved by the local Ethics Committee of the Pomeranian Medical University (Ref. KB-0012/54/10). All the subjects were normotensive, were taking no medications, and their body mass index (BMI) was between 24.8 and $26.3 \mathrm{~kg} / \mathrm{m}^{2}$. The daily physical activity of the respondents was $4-5 \mathrm{~h}$ per week. The participants were randomly divided into an experimental group of 30 and a control group of 15 men. The groups were homogeneous in terms of age, diet and daily physical activity, due to the scheduled joint activities, accommodation and food provided by the 
Military Academy. During the experiment, the participants were required not to change the duration or intensity of their daily training and diet. Anthropometrical parameters (as well as BMI index), didn't changed significant during the period of the study. The anthropometric characteristics of the participants are presented in Table 1.

Table 1. Anthropometric characteristics of the subjects.

\begin{tabular}{|c|c|c|c|c|c|c|c|c|}
\hline \multirow{2}{*}{ Parameter } & \multicolumn{2}{|c|}{ Age (years) } & \multicolumn{2}{|c|}{ Height (cm) } & \multicolumn{2}{|c|}{ Body weight (kg) } & \multicolumn{2}{|c|}{ BMI $\left(\mathrm{kg} / \mathrm{m}^{2}\right)$} \\
\hline & $\mathbf{S}$ & $\mathbf{C}$ & $\mathbf{S}$ & $\mathrm{C}$ & $\mathbf{S}$ & $\mathbf{C}$ & $\mathbf{S}$ & $\mathrm{C}$ \\
\hline$\chi$ & 23.6 & 23.6 & 179.8 & 177.1 & 79.1 & 76.9 & 25.1 & 24.7 \\
\hline $\pm S D$ & 0.8 & 0.9 & 3.9 & 6.19 & 8.0 & 5.30 & 2.13 & 2.35 \\
\hline $\min$ & 23 & 22 & 174 & 169 & 67 & 67 & 21.5 & 22.2 \\
\hline $\max$ & 26 & 25 & 187 & 190 & 100 & 89 & 29.9 & 30.5 \\
\hline
\end{tabular}

BMI - body mass index; $\mathrm{S}$ - study group; $\mathrm{C}$ - control group.

\section{Cryostimulation procedure}

The systemic cryotherapy procedure was conducted by means of 30 daily entries into a cryogenic chamber $\left(3 \mathrm{~min} ;-130^{\circ} \mathrm{C}\right)$, during the autumn season. Before each intervention, systolic and diastolic blood pressures were measured. During the cryostimulation procedure, the subjects were dressed only in shorts, socks, wooden clogs, gloves and a hat covering the auricles against frostbite, noses and mouths were secured with a surgical mask.

\section{Blood sampling and analysis}

Venous blood samples were collected in the morning before the first session (T0), in the morning on the day following the $10^{\text {th }}$ session (T1), and respectively after the $20^{\text {th }}$ (T2) and the $30^{\text {th }}$ sessions (T3). In order to assess persistence of the potential changes, a month after the whole series of sessions (T4). Blood samples were always obtained after overnight fasting, between 6:00 and 7:30 a.m., after a 10-minute rest in the sitting position, from the antecubital forearm, separately into two tubes, one with an appropriate amount of $\mathrm{K}_{2}$ EDTA anticoagulant (Sarstedt, Germany) to obtain whole blood to determine blood count $(1.2 \mathrm{ml})$, and the second, dry tube $(5 \mathrm{ml})$ in order to obtain blood serum. In blood serum, total protein, albumin and uric acid levels and lipid profile indicators: total cholesterol, HDL cholesterol and triglyceride concentrations, were determined with the enzymatic colorimetric method using appropriate commercial kits (BioMaxima, Poland). The HSP-70 protein levels were determined using commercially available enzyme-linked immunosorbent assay (ELISA) kits (EIAab, Wuhan, China). The standard curve has a range of $0.2-10 \mathrm{ng} / \mathrm{ml}$, the intra-assay: $<8 \%$ and inter-assay: $<10 \%$. The serum levels of apolipoprotein $A$ (ApoA-I) and apolipoprotein B (ApoB) were determined using commercially available ELISA kits (EIAab, Wuhan, China), according to the instruction given by the manufacturer. The detection limits for lipoprotein tests are 0.8 and $892.9 \mu \mathrm{mol} / 1$, the intra-assay: $<8 \%$ and inter-assay: $<10 \%$. Having the analyzed parameters, it was possible to calculate additional indicators of lipid metabolism. The LDL-cholesterol fraction was calculated using the Friedewald formula, which can be used with TG values not exceeding $4.5 \mathrm{mmol} / \mathrm{l}$ : $\mathrm{LDL}[\mathrm{mg} / \mathrm{dl}]=$ total cholesterol (TCh) - HDL cholesterol - (TG/5) (Ciach et al. 2011).

The lipid index (LI) was also calculated, from the Wochyński and Sobiech formula (Karmowski et al. 2005):

$$
L I=\frac{\left(H D L+\frac{T G}{6}\right) \times \frac{A p o A_{1}}{30} \times 10}{\left(L D L+\frac{T G}{5}\right) \times \frac{A p o B}{20}}
$$

In addition, the following ratios were calculated: TG:TCh, TCh:HDL, LDL:HDL.

\section{Statistical analysis}

Statistical analysis was performed using the Statistica 10 package. The data were checked for normal distribution (Shapiro-Wilk test). The data were tested by a non-parametric Friedman ANOVA. The Pearson's correlation coefficient was employed to test the 
association of HSP-70 protein and biochemical parameters. The U Mann-Whitney test was used to compare the study and control group. The accepted level of significance was defined at $\mathrm{p}<0.05$.

\section{Results}

The examined groups did not show any significant differences in the baseline values (T0) of the BMI and concentrations of analyzed blood biochemical parameters, including those relating to lipid profile and HSP-70 protein (Tables 2 and 3). After 10 intervention sessions of daily WBC, a significant and sustained increase in the concentrations of total protein and albumin was recorded, from the baseline values $71.7 \pm 7.6 \mathrm{~g} / 1$ for protein and $49.41 \pm 6.1 \mathrm{~g} / 1$ for albumin up to $78.52 \pm 15.0 \mathrm{~g} / 1$ and $61.4 \pm 9.5 \mathrm{~g} / 1$, respectively, after a series of $30 \mathrm{WBC}$ sessions. Higher concentrations, in relation to both baseline values and the control group, persisted a month after the application of whole-body cryostimulation. The concentration of uric acid initially decreased (after 10 sessions), then significantly increased after a series of 30 sessions and remained higher, compared to the control group, also one month after the end of WBC. Although there were not such significant changes in the biochemical parameters in the control group, we noticed small changes in albumin (transient increase) and uric acid (decrease) concentration during the intervention period, comparing to initial levels.
Interesting observations are related to serum HSP-70 protein concentration. In the study group, the HSP-70 concentration remained relatively comparable in the successive days of exposure. Only after a series of 30 intervention sessions, a significant increase in the HSP-70 concentration was recorded, from the baseline value $0.71 \pm 0.3$ to $1.09 \pm 0.3 \mathrm{ng} / \mathrm{ml}$, remaining at the level of $1.08 \pm 0.5 \mathrm{ng} / \mathrm{ml}$ one month after the end of cryostimulation intervention. Interestingly, in the group not exposed to cryostimulation, an increase in the concentration of this protein was observed from as early as the first weeks of starting the experiment, being enhanced during it to $1.13 \pm 0.7 \mathrm{ng} / \mathrm{ml}$ in the time corresponding to 30 intervention sessions for the study group and reaching a significantly higher value than in the study group being equal to $1.29 \pm 0.9 \mathrm{ng} / \mathrm{ml}$ one month after the end of cryostimulation intervention (Table 2). When considering the changes in lipid profile (Table 3), a significant decrease in the TCh concentration, initiated after the $20^{\text {th }}$ intervention session $\left(\mathrm{T}_{2}\right)$ and enhanced during the continued intervention, with a simultaneous decrease in TG and LDL cholesterol levels and an increase in the HDL cholesterol concentration, was observed. Thirty daily intervention sessions induced a significant decrease in the TCh concentration from $4.82 \pm 0.9$ to $4.49 \pm 1.2 \mathrm{mmol} / \mathrm{l}$, LDL cholesterol from $3.05 \pm 0.9$ to $2.74 \pm 1.0 \mathrm{mmol} / \mathrm{l}$, and TG from $1.42 \pm 0.6$ to $1.27 \pm 0.4 \mathrm{mmol} / \mathrm{l}$, with a simultaneous increase in the concentration of HDL cholesterol from $1.23 \pm 0.1$ to

Table 2. Changes in the concentrations of selected blood biochemical parameters in the course of successive WBC exposures.

\begin{tabular}{|c|c|c|c|c|c|c|c|c|c|c|}
\hline \multirow{2}{*}{ Parameter } & \multicolumn{2}{|c|}{$\mathbf{T}_{\mathbf{0}}$} & \multicolumn{2}{|c|}{$\mathbf{T}_{1}$} & \multicolumn{2}{|c|}{$\mathbf{T}_{2}$} & \multicolumn{2}{|c|}{$\mathbf{T}_{3}$} & \multicolumn{2}{|c|}{$\mathbf{T}_{4}$} \\
\hline & $\mathbf{S}$ & $\mathrm{C}$ & $\mathbf{S}$ & C & $\mathbf{S}$ & C & $\mathbf{S}$ & C & $\mathbf{S}$ & C \\
\hline $\begin{array}{l}\text { Protein } \\
(g / l)\end{array}$ & $71.70 \pm 7.6$ & $72.60 \pm 6.3$ & $\begin{array}{c}75.60 \pm 10.8 \\
* \mathrm{~T}_{0 \mathrm{~S}},{ }^{*} \mathrm{~T}_{1 \mathrm{C}}\end{array}$ & $72.00 \pm 6$ & $\begin{array}{c}77.50 \pm 12.8 \\
* \mathrm{~T}_{0 \mathrm{~S}}, * \mathrm{~T}_{2 \mathrm{C}}\end{array}$ & $71.21 \pm 12.0$ & $\begin{array}{l}78.52 \pm 15 \\
* \mathrm{~T}_{0 \mathrm{~S}}, * \mathrm{~T}_{3 \mathrm{C}}\end{array}$ & $69.92 \pm 6.9$ & $\begin{array}{l}76.73 \pm 14.9 \\
* * \mathrm{~T}_{0 \mathrm{~S}},{ }^{*} \mathrm{~T}_{4 \mathrm{C}}\end{array}$ & $69.14 \pm 6.7$ \\
\hline $\begin{array}{l}\text { Albumin } \\
(\mathrm{g} / \mathrm{l})\end{array}$ & $49.41 \pm 6.1$ & $50.40 \pm 7.0$ & $\begin{array}{c}54.33 \pm 1.9 \\
{ }^{* *} \mathrm{~T}_{0 \mathrm{~S}}\end{array}$ & $55.71 \pm 1.2$ & $\begin{array}{c}55.70 \pm 9.3 \\
* * \mathrm{~T}_{0 \mathrm{~S}} * \mathrm{~T}_{2 \mathrm{C}}\end{array}$ & $53.74 \pm 10.9$ & $\begin{array}{c}61.40 \pm 9.5 \\
* * * \mathrm{~T}_{0 \mathrm{~S}} \\
* \mathrm{~T}_{1 \mathrm{~S}}, * * \mathrm{~T}_{2 \mathrm{~S}}\end{array}$ & $\begin{array}{c}57.42 \pm 7.8 \\
* \mathrm{~T}_{0 \mathrm{C}}\end{array}$ & $\begin{array}{c}56.40 \pm 3.5 \\
\quad * * \mathrm{~T}_{0 \mathrm{~S}} \\
{ }^{* *} \mathrm{~T}_{4 \mathrm{C}}\end{array}$ & $\begin{array}{c}50.60 \pm 6.8 \\
* \mathrm{~T}_{1 \mathrm{C}}\end{array}$ \\
\hline $\begin{array}{l}\text { Uric acid } \\
(\mathrm{mmol} / \mathrm{l})\end{array}$ & $0.33 \pm 0.1$ & $0.33 \pm 0.9$ & $\begin{array}{c}0.31 \pm 0.1 \\
* \mathrm{~T}_{0 \mathrm{~S}}\end{array}$ & $0.33 \pm 0.1$ & $0.34 \pm 0.1$ & $0.33 \pm 0.2$ & $\begin{array}{c}0.39 \pm 0.1 \\
* \mathrm{~T}_{1 \mathrm{~S}}, * \mathrm{~T}_{2 \mathrm{~S}} \\
* \mathrm{~T}_{3 \mathrm{C}}\end{array}$ & $\begin{array}{c}0.31 \pm 0.1 \\
* \mathrm{~T}_{0 \mathrm{C}}\end{array}$ & $\begin{array}{c}0.39 \pm 0.1 \\
* \mathrm{~T}_{1 \mathrm{~S}} * \mathrm{~T}_{2 \mathrm{~S}} \\
* \mathrm{~T}_{4 \mathrm{C}}\end{array}$ & $\begin{array}{c}0.32 \pm 0.7 \\
* \mathrm{~T}_{0 \mathrm{C}}\end{array}$ \\
\hline $\begin{array}{l}H S P-70 \\
(\mathrm{ng} / \mathrm{ml})\end{array}$ & $0.71 \pm 0.3$ & $0.70 \pm 0.2$ & $0.69 \pm 0.3$ & $\begin{array}{c}0.80 \pm 0.3 \\
* \mathrm{~T}_{0 \mathrm{C}}\end{array}$ & $\begin{array}{c}0.69 \pm 0.4 \\
* \mathrm{~T}_{0 \mathrm{~s}}\end{array}$ & $\begin{array}{c}0.89 \pm 0.6 \\
* \mathrm{~T}_{0 \mathrm{C}}\end{array}$ & $\begin{array}{c}1.09 \pm 0.3 \\
* * \mathrm{~T}_{0 \mathrm{~S}} \\
* * \mathrm{~T}_{1 \mathrm{~S}} \\
* * \mathrm{~T}_{2 \mathrm{~S}}\end{array}$ & $\begin{array}{c}1.13 \pm 0.7 \\
* * \mathrm{~T}_{0 \mathrm{C}} \\
* * \mathrm{~T}_{1 \mathrm{C}}\end{array}$ & $\begin{array}{c}1.08 \pm 0.5 \\
* * \mathrm{~T}_{0 \mathrm{~S}} \\
* * \mathrm{~T}_{1 \mathrm{~S}} \\
* * \mathrm{~T}_{2 \mathrm{~S}} \\
* * \mathrm{~T}_{4 \mathrm{C}}\end{array}$ & $\begin{array}{c}1.29 \pm 0.9 \\
* * \mathrm{~T}_{0 \mathrm{C}} \\
* * \mathrm{~T}_{1 \mathrm{C}} \\
* * \mathrm{~T}_{2 \mathrm{C}}\end{array}$ \\
\hline
\end{tabular}

$\mathbf{T}_{\mathbf{0}}$ - before the first WBC; $\mathbf{T}_{\mathbf{1}}$ - after the $10^{\text {th }} \mathrm{WBC} ; \mathbf{T}_{\mathbf{2}}$ - after the $20^{\text {th }} \mathrm{WBC} ; \mathbf{T}_{\mathbf{3}}-$ after the $30^{\text {th }} \mathrm{WBC} ; \mathbf{T}_{\mathbf{4}}-$ a month after the whole series of intervention session; $\mathbf{S}$ - study group; $\mathbf{C}$ - control group $(* p<0.05, * * p<0.01, * * * p<0.001)$. 
Table 3. Changes in the selected lipid metabolism parameters in the course of successive WBC exposures.

\begin{tabular}{|c|c|c|c|c|c|c|c|c|c|c|}
\hline \multirow{2}{*}{ Parameter } & \multicolumn{2}{|c|}{$\mathbf{T}_{\mathbf{0}}$} & \multicolumn{2}{|c|}{$T_{1}$} & \multicolumn{2}{|c|}{$\mathbf{T}_{2}$} & \multicolumn{2}{|c|}{$\mathbf{T}_{3}$} & \multicolumn{2}{|c|}{$\mathbf{T}_{4}$} \\
\hline & $\mathbf{S}$ & C & $\mathbf{S}$ & C & $\mathbf{S}$ & C & $\mathbf{S}$ & C & $\mathbf{S}$ & $\mathrm{C}$ \\
\hline $\begin{array}{l}\text { TCh } \\
\text { (mmol/l) }\end{array}$ & $4.82 \pm 0.9$ & $5.01 \pm 1$ & $4.70 \pm 1.2$ & $4.71 \pm 0.5$ & $\begin{array}{c}4.54 \pm 1.1 \\
* \mathrm{~T}_{0 \mathrm{~S}}\end{array}$ & $5.14 \pm 1.5$ & $\begin{array}{c}4.49 \pm 1.2 \\
* * \mathrm{~T}_{0 \mathrm{~S}}\end{array}$ & $\begin{array}{c}5.19 \pm 0.9 \\
* \mathrm{~T}_{1 \mathrm{C}}\end{array}$ & $4.83 \pm 1$ & $4.94 \pm 1.3$ \\
\hline $\begin{array}{l}L D L \\
(\mathrm{mmol} / \mathrm{l})\end{array}$ & $3.05 \pm 0.9$ & $3.12 \pm 0.9$ & $2.69 \pm 1.2$ & $3.04 \pm 0.5$ & $\begin{array}{c}2.52 \pm 1.0 \\
* \mathrm{~T}_{2 \mathrm{C}}\end{array}$ & $3.36 \pm 1.3$ & $\begin{array}{c}2.74 \pm 1.0 \\
\quad * \mathrm{~T}_{3 \mathrm{C}}\end{array}$ & $3.46 \pm 0.9$ & $\begin{array}{c}2.82 \pm 1.0 \\
* * \mathrm{~T}_{4 \mathrm{C}}\end{array}$ & $3.15 \pm 1.2$ \\
\hline $\begin{array}{l}\text { HDL } \\
(\mathrm{mmol} / \mathrm{l})\end{array}$ & $1.23 \pm 0.1$ & $1.22 \pm 0.1$ & $1.30 \pm 0.1$ & $1.24 \pm 0.1$ & $\begin{array}{c}1.52 \pm 0.2 \\
* * * \mathrm{~T}_{0 \mathrm{~S}} \\
* * * \mathrm{~T}_{1 \mathrm{~S}}\end{array}$ & $\begin{array}{l}1.26 \pm 0.1 \\
* * * \mathrm{~T}_{2 \mathrm{~S}}\end{array}$ & $\begin{array}{c}1.54 \pm 0.3 \\
* * * \mathrm{~T}_{0 \mathrm{~S}} \\
* * * \mathrm{~T}_{1 \mathrm{~S}}\end{array}$ & $\begin{array}{c}1.32 \pm 0.1 \\
* * \mathrm{~T}_{3 \mathrm{~S}}\end{array}$ & $\begin{array}{c}1.34 \pm 0.3 \\
* * * \mathrm{~T}_{2 \mathrm{~S}} \\
* * * \mathrm{~T}_{3 \mathrm{~S}}\end{array}$ & $1.21 \pm 0.1$ \\
\hline $\begin{array}{l}T G \\
(\mathrm{mmol} / \mathrm{l})\end{array}$ & $1.42 \pm 0.6$ & $1.43 \pm 0.6$ & $1.40 \pm 0.5$ & $1.41 \pm 0.3$ & $\begin{array}{c}1.26 \pm 0.7 \\
* * \mathrm{~T}_{0 \mathrm{~S}} \\
* * \mathrm{~T}_{1 \mathrm{~S}}\end{array}$ & $1.39 \pm 0.6$ & $\begin{array}{c}1.27 \pm 0.4 \\
* * \mathrm{~T}_{0 \mathrm{~S}} \\
* * \mathrm{~T}_{1 \mathrm{~S}}\end{array}$ & $1.41 \pm 0.4$ & $\begin{array}{l}1.25 \pm 0.6 \\
* * * \mathrm{~T}_{0 \mathrm{~S}} \\
* * * \mathrm{~T}_{1 \mathrm{~S}}\end{array}$ & $1.51 \pm 0.4$ \\
\hline $\begin{array}{l}\text { ApoA-I } \\
(\mu \mathrm{mol} /)\end{array}$ & $85.71 \pm 6.8$ & $79.33 \pm 20.4$ & $87.11 \pm 3.9$ & $75.72 \pm 20.4$ & $\begin{array}{c}77.10 \pm 20.7 \\
* \mathrm{~T}_{1 \mathrm{~S}}\end{array}$ & $80.01 \pm 21.4$ & $81.12 \pm 11.1$ & $72.50 \pm 19.3$ & $78.61 \pm 13.9$ & $74.30 \pm 19.6$ \\
\hline $\begin{array}{l}\text { ApoB } \\
(\mu \mathrm{mol} / \mathrm{l})\end{array}$ & $1.13 \pm 0$ & $1.12 \pm 0.1$ & $1.12 \pm 0.1$ & $1.10 \pm 0.1$ & $\begin{array}{l}1.04 \pm 0.1 \\
* * * \mathrm{~T}_{0 \mathrm{~S}} \\
* * * \mathrm{~T}_{1 \mathrm{~S}}\end{array}$ & $1.02 \pm 0.1$ & $\begin{array}{c}1.03 \pm 0.1 \\
* * * \mathrm{~T}_{0 \mathrm{~S}} \\
* * * \mathrm{~T}_{1 \mathrm{~S}}\end{array}$ & $\begin{array}{c}1.06 \pm 0.1 \\
* \mathrm{~T}_{3 \mathrm{~S}}\end{array}$ & $\begin{array}{c}0.9 \pm 0.1 \\
* * * \mathrm{~T}_{0 \mathrm{~S}} \\
* * * \mathrm{~T}_{1 \mathrm{~S}} \\
{ }^{*} \mathrm{~T}_{2 \mathrm{~S}}\end{array}$ & $\begin{array}{l}1.02 \pm 0.1 \\
* * * \mathrm{~T}_{4 \mathrm{~S}}\end{array}$ \\
\hline$L I$ & $16.3 \pm 4.6$ & $13.7 \pm 4.9$ & $\begin{array}{c}21.0 \pm 9.5 \\
* \mathrm{~T}_{0 \mathrm{~S}}\end{array}$ & $\begin{array}{c}13.3 \pm 3.8 \\
* * \mathrm{~T}_{1 \mathrm{~S}}\end{array}$ & $23.5 \pm 11$ & $\begin{array}{c}15.0 \pm 4.6 \\
* \mathrm{~T}_{2 \mathrm{~S}}\end{array}$ & $17.0 \pm 12.6$ & $13.34 \pm 4.8$ & $\begin{array}{c}13.8 \pm 5.2 \\
* \mathrm{~T}_{1 \mathrm{~S}}\end{array}$ & $16.8 \pm 9.6$ \\
\hline
\end{tabular}

$\mathbf{T}_{\mathbf{0}}$ - before the first WBC; $\mathbf{T}_{\mathbf{1}}-$ after the $10^{\text {th }} \mathrm{WBC} ; \mathbf{T}_{\mathbf{2}}-$ after the $20^{\text {th }} \mathrm{WBC} ; \mathbf{T}_{\mathbf{3}}-$ after the $30^{\text {th }} \mathrm{WBC} ; \mathbf{T}_{\mathbf{4}}-$ a month after the whole series of intervention session; $\mathbf{S}$ - study group; $\mathbf{C}$ - control group; $(* p<0.05, * * p<0.01, * * * p<0.001)$.

$1.54 \pm 0.3 \mathrm{mmol} / 1$. At the same time, these changes had a positive effect on the values of TCh:HDL and LDL:HDL ratios (Table 4). No significant changes were observed in lipid profile in the subjects of the control group (only a slight transitional increases in $\mathrm{TCh}-\mathrm{T} 3$ ). Along with changes in respective cholesterol fractions, a downward trend was observed in the ApoB concentrations. As early as 20 intervention sessions, a significant decrease in the ApoB concentrations was recorded $(1.04 \pm 0.1 \mu \mathrm{mol} / \mathrm{l})$, with a further decrease in its concentrations, reaching $0.9 \pm 0.1 \mu \mathrm{mol} / 1$ one month after the end of exposure to cryogenic temperatures, being observed in the next weeks. After the $30^{\text {th }} \mathrm{WBC}$ and one month after the exposure, these values were significantly lower in the study group compared to the control one. The concentration of ApoA-I decreased in the study group only temporarily after 20 intervention sessions, and then returned to the values comparable to the baseline ones. In the control group, no significant changes in the concentration of both ApoA-I and ApoB were observed during the study. As a consequence, a decrease in the ApoB:ApoA-I ratio was observed after 30 intervention sessions which was significantly lower in the study group compared to the control one (Table 4). The discussed changes were accompanied by a resulting increase in the value of LI index in the next weeks of the study during prolonged whole-body cryostimulation (Table 3 ).

When analyzing the relationships between the HSP-70 level and the analyzed lipid indicators, a negative correlation with the ApoA-I concentration $(\mathrm{r}=-0.44$; $\mathrm{p}=0.0052)$ and a positive one with the TG level $(\mathrm{r}=0.61$; $\mathrm{p}=0.0001)$ and the TG:TCh ratio $(\mathrm{r}=0.59 ; \mathrm{p}=0.003)$ was demonstrated only after a series of 20 intervention sessions in the study group (Fig. 1). No significant relationships were observed within the control group.

\section{Discussion}

Interventions with the use of cryogenic temperatures are now becoming one of the basic procedures, being common in sports medicine and rehabilitation; a possibility to use the systemic effect of extremely low temperatures to reduce body weight and subcutaneous fat content, which could have a positive effect on lipid metabolism parameters and prevention of such diseases as diabetes, atherosclerosis or metabolic syndrome, is also postulated. 
Table 4. Changes in the values of lipid indicators in the course of successive WBC exposures.

\begin{tabular}{|c|c|c|c|c|c|c|c|c|c|c|}
\hline \multirow{2}{*}{ Parameter } & \multicolumn{2}{|c|}{$\mathbf{T}_{\mathbf{0}}$} & \multicolumn{2}{|c|}{$T_{1}$} & \multicolumn{2}{|c|}{$T_{2}$} & \multicolumn{2}{|c|}{$\mathbf{T}_{3}$} & \multicolumn{2}{|c|}{$\mathbf{T}_{4}$} \\
\hline & $\mathbf{S}$ & C & $\mathbf{S}$ & C & $\mathbf{S}$ & C & $\mathbf{S}$ & C & $\mathbf{S}$ & $\mathbf{C}$ \\
\hline$T G: T C h$ & $0.7 \pm 0.3$ & $0.7 \pm 0.3$ & $0.7 \pm 0.3$ & $0.5 \pm 0.1$ & $0.6 \pm 0.4$ & $\begin{array}{c}0.6 \pm 0.2 \\
* * \mathrm{~T}_{1 \mathrm{C}}\end{array}$ & $0.7 \pm 0.3$ & $\begin{array}{c}0.5 \pm 0.1 \\
* * \mathrm{~T}_{3 \mathrm{~S}}\end{array}$ & $\begin{array}{c}0.8 \pm 0.4 \\
* * \mathrm{~T}_{2 \mathrm{~S}}\end{array}$ & $\begin{array}{c}0.6 \pm 0.2 \\
* \mathrm{~T}_{4 \mathrm{~S}}\end{array}$ \\
\hline TCh:HDL & $4.1 \pm 0.9$ & $4.2 \pm 0.7$ & $3.7 \pm 1.0$ & $4.0 \pm 0.6$ & $\begin{array}{c}2.9 \pm 0.7 \\
* \mathrm{~T}_{0 \mathrm{~S}}\end{array}$ & $\begin{array}{l}4.4 \pm 1.2 \\
* * * \mathrm{~T}_{2 \mathrm{~S}}\end{array}$ & $3.2 \pm 0.8$ & $\begin{array}{l}4.1 \pm 0.8 \\
* * * \mathrm{~T}_{3 \mathrm{~S}}\end{array}$ & $\begin{array}{c}4.0 \pm 1.5 \\
* \mathrm{~T}_{2 \mathrm{~S}}, \mathrm{~T}_{3 \mathrm{~S}}\end{array}$ & $\begin{array}{c}3.9 \pm 1 \\
* \mathrm{~T}_{2 \mathrm{~S}},{ }^{*} \mathrm{~T}_{3 \mathrm{~S}}\end{array}$ \\
\hline$L D L: H D L$ & $2.6 \pm 0.9$ & $2.6 \pm 0.7$ & $2.2 \pm 1$ & $2.6 \pm 0.6$ & $\begin{array}{c}1.6 \pm 0.7 \\
* \mathrm{~T}_{0 \mathrm{~s}}\end{array}$ & $\begin{array}{l}2.8 \pm 1.1 \\
* * * \mathrm{~T}_{2 \mathrm{~S}}\end{array}$ & $\begin{array}{c}1.8 \pm 0.6 \\
* \mathrm{~T}_{0 \mathrm{~S}}\end{array}$ & $\begin{array}{l}2.7 \pm 0.8 \\
* * * \mathrm{~T}_{3 \mathrm{~S}}\end{array}$ & $\begin{array}{c}2.4 \pm 1.3 \\
* \mathrm{~T}_{2 \mathrm{~S}}, * \mathrm{~T}_{3 \mathrm{~S}}\end{array}$ & $2.5 \pm 1$ \\
\hline ApoB:ApoA & $0.01 \pm 0$ & $0.02 \pm 0$ & $0.01 \pm 0$ & $0.02 \pm 0$ & $0.01 \pm 0$ & $0.01 \pm 0$ & $\begin{array}{c}0.01 \pm 0 \\
* \mathrm{~T}_{2 \mathrm{~S}}\end{array}$ & $\begin{array}{l}0.02 \pm 0 \\
* * * \mathrm{~T}_{3 \mathrm{~S}}\end{array}$ & $0.01 \pm 0$ & $\begin{array}{l}0.02 \pm 0 \\
* * \mathrm{~T}_{4 \mathrm{~S}}\end{array}$ \\
\hline
\end{tabular}

$\mathbf{T}_{\mathbf{0}}$ - before the first WBC; $\mathbf{T}_{\mathbf{1}}-$ after the $10^{\text {th }} \mathrm{WBC} ; \mathbf{T}_{\mathbf{2}}$ - after the $20^{\text {th }} \mathrm{WBC} ; \mathbf{T}_{\mathbf{3}}-$ after the $30^{\text {th }} \mathrm{WBC} ; \mathbf{T}_{\mathbf{4}}-$ a month after the whole series of intervention session; $\mathbf{S}$ - study group; $\mathbf{C}$ - control group; $(* \mathrm{p}<0.05, * * \mathrm{p}<0.01, * * * \mathrm{p}<0.001)$.
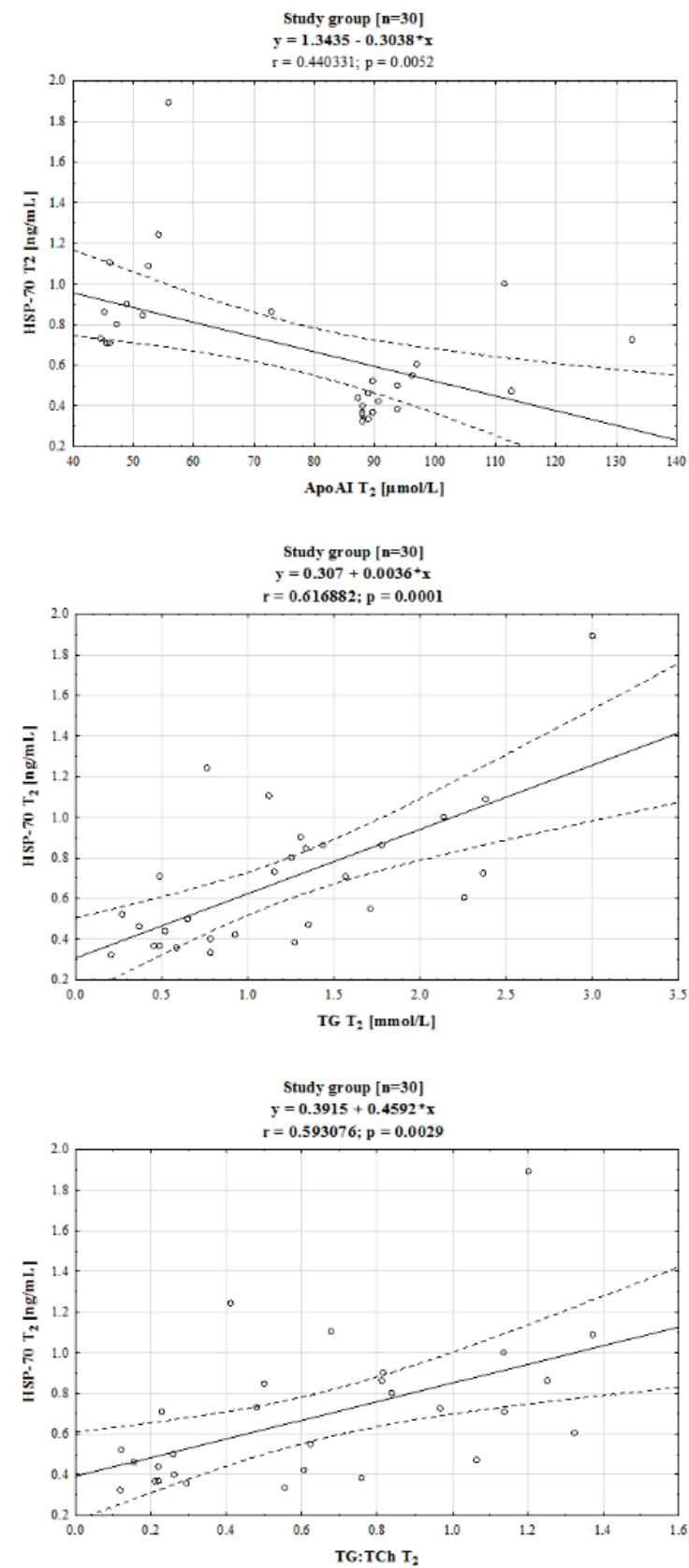

Fig. 1. The significant correlation between HSp70 level and lipid indicators after a series of 20 WBC.

An example of such application of low temperatures could be cryolipolysis and whole-body cryostimulation. Clinical evaluation of cryolipolysis demonstrates the selective reduction of body fat, but most studies have confirmed that cosmetically significant fat layer reduction by cryolipolysis is not associated with changes in serum lipid profile (Ferraro et al. 2012, Klein et al. 2009). The main hormonal response to cold stimulation is activation of the hypothalamic-pituitaryadrenal (HPA) axis as a reaction typical for stressors (Herman et al. 2016, Smith and Vale 2006). During the acute cold exposure, the fuel substrates for shivering thermogenesis are lipids, muscle glycogen, plasma glucose and proteins. The major store of energy for rapid response is triglycerides being located in the adipose tissue, therefore the thermoregulation mechanism associated with exposure to cold is closely linked to increased lipid metabolism (Skrzep-Poloczek et al. 2002, Haman et al. 2002). In response to stimulation by cold, there is a change in secretion of thyroid stimulating hormone (TSH), thyroid hormones (T3, T4) (Hassi et al. 2001), noradrenalin and adrenalin (Cannon et al. 2004), insulin and glucagon (Leppäluoto et al. 2005), cortisol, adrenocorticotrophic hormone (ACTH), aldosterone and growth hormone (GH) (Hiramatsu et al. 1984, Leppäluoto et al. 1981). Biochemical explanations of fat mobilization in cold include increased secretion of catecholamines, increased sensitivity of peripheral catecholamine receptors and decreased circulating levels of insulin (Brojek and Warzocha 2006). Based on the 
current knowledge and previous findings, we posed a hypothesis about the possibility of positive adaptive changes in the organism that lead to modification of the level of lipid indicators following the prolonged exposure to cold during whole-body cryostimulation interventions, seeing the potentials of cryostimulation in the regulation of hyperlipidemia and thereby in the prevention of cardiovascular diseases. In our previous study, we have observed that significant positive changes in lipid profile (LDL decrease with a simultaneous HDL increase) occur after at least 15 intervention sessions of WBC (Lubkowska et al. 2010c). The present study pays particular attention to prolonged time of exposure to 30 daily sessions, selection of the subjects being very homogenous in terms of lifestyle, and assessment of the persistence of possible effects. Obese men $\left(\mathrm{BMI}>30 \mathrm{~kg} / \mathrm{m}^{2}\right)$ and underfed ones $\left(\mathrm{BMI}<20 \mathrm{~kg} / \mathrm{m}^{2}\right)$ were not qualified. Moreover, during the study, all the participants (both from the exposed group and the control one) followed a comparable diet (they enjoyed uniform institutional catering as residents of the academy's dormitory and students of the same year), showed comparable level of physical activity, and did not use any preparations reducing the cholesterol concentration. This way we tried to limit the effect of other factors than cryogenic temperatures that could modify the lipid profile. This is a very important element of the study since it is known that proper diet, or aerobic physical activity corresponding to total energy expenditure amounting to $1,500-2,200 \mathrm{kcal} /$ week could affect the concentration LDL, or even that of HDL cholesterol (Kraus et al. 2002). The changes in biochemical and lipid metabolism indicators observed in our study confirm the previous results and point to the benefits from prolonged exposure to cryogenic temperatures (Lubkowska et al. 2010c). During the experimental period as well as one month following, we observed increased in albumin concentration (in this case dependent not only on nutritional intake with both groups, but mostly by WBC in study group), and respectively total protein. Albumin is the main protein of blood plasma, assists in many important body functions, including maintenance of proper colloidal osmotic pressure, transport of important metabolites and antioxidant action. It could be suggest that antioxidative potential of cryostimulation treatment lead to this biochemical changes in albumin level. Moreover it is possible that cold stimulation with following vasoconstriction and vasodilatation could lead to changes in albumin penetration into extravascular compartments as well as an increase in lymphatic return to the intravascular compartment.

The effects of cold stress on the induction of HSPs are still not known. It is widely accepted that the levels of HSP-70 expression increase under stressful conditions (Ireland et al. 2007). The induction of HSPs in brown adipose tissue in mice exposed to cold ambient temperature has been shown to be mediated by norepinephrine released in response to cold (Fujita 1999, Matz et al. 1995). According to HSP-70 protein concentration changes during described intervention one cannot clearly interpret that it resulted from the impact of extremely low temperatures because changes in the level of HSP-70 protein were of the same nature in exposed and unexposed group and, what more, the increased HSP-70 concentration occurred much earlier in the control group. In this study, the relationships between the concentration of HSP-70 proteins and the lipid indicators were sought. Interestingly enough, they occurred only in the study group after the application of 20 sessions, with a decreased ApoA-I concentration in this study period (inverse relationship) and that of $\mathrm{TG}$ and $\mathrm{TG}$ : $\mathrm{TCh}$ ratio (positive relationship), which coincided with the most positive changes in the lipid profile of the subjects. According to these results, it could be postulated that 20 daily sessions of daily WBC intervention during following four weeks is the smallest required number of treatments that could cause significant adaptive metabolic changes in humans. The observed decrease in $\mathrm{TCh}$, LDL-Ch, TG and ApoB concentrations, with accompanying increased HDL-TCh level and LI and decreased ApoB:ApoA-I ratio, provides a basis for conclusion that there is a possibility of lipid metabolism modification on the basis of whole-body cryostimulation. Both the amount of individual lipoproteins and the ratio of apoproteins created de novo by cells and secreted into the extracellular space to apoproteins derived from plasma are not constant and change depending on the metabolic state of the body. The probable mechanism of which the concentration of TCh is lower in the event of cold influence may be the regulation of the return transport, as it happens under the influence of physical activity. There are many factors that affect the HDL concentration, included: body weight, female sex, intense physical activity, consumption of small amounts of alcohol, estrogens, and glucocorticoids (Singh et al. 2007); perhaps the repeated whole-body exposure to low temperatures could be attached to this group of factors. The amount of HDL is assessed most often by measuring 
the concentration of cholesterol being transported in this lipoprotein fraction. A more specific indicator of the HDL amount is the ApoA-I concentration which is not only - quantitatively speaking - the main protein of HDL but also plays a major role in reverse cholesterol transport. Although LDL-Ch is widely recognized as the major atherogenic lipoprotein and the primary target of lipid-lowering therapy, we decided in our study to also determine ApoB and ApoA-I concentrations in addition to basic indicators of the lipid profile. Therefore, it seems particularly important to reduce the concentration of ApoB lipoprotein and positively change the ApoB:ApoA-I ratio and LI during the prolonged exposure.

Data on the impact of low temperatures on changes in lipid metabolism are limited, and the findings are inconclusive and based on highly diversified experimental models. There is an evidence that the coldinduced increase in lipid oxidation in man is fueled primarily by the fatty acids released from white adipose tissue and possibly intramuscular TG (Vallerand and Jacobs 1992). Heat production is immediately increased in skeletal muscles after cold exposure, shivering thermogenesis decreases during cold acclimation and is progressively replaced by non-shivering thermogenesis mainly in brown adipose tissue in cold adapted organisms (Vallerand et al. 1986). Haman et al. (2002) have observed that heat production during prolonged, low-intensity shivering is unequally shared among lipids $(50 \%)$, muscle glycogen $(30 \%)$, circulating glucose $(10 \%)$, and proteins $(10 \%)$. These components of energy store can be dissociated from sympathetic neural modulation of thermogenesis and from the modulation of uncoupling protein (UCP) activity in brown adipose tissue (BAT), an important site of sympathetically mediated thermogenesis (Samec et al. 1998). Upon coldstimulated activation by nervous input, BAT defends the body against cold, increases its energy demand and burns carbohydrates and lipids to produce heat using uncoupling protein-1 (UCP1), a protein that uncouples electron transport from ATP production. It is also known that a 3-minute of- $130{ }^{\circ} \mathrm{C}$ WBC intervention leads to significant drops in surface body temperature without reduction of core body temperature (Chudecka et al. 2008) and is associated with heat loss of $62.5 \mathrm{kcal}$ (Suszko 2003). Cold is sensed in the central nervous system and "cold-induced" expression of several genes, e.g. uncoupling protein-1 (UCP1) and PGC-1, is mediated by increased "sympathetic" output to peripheral tissues (Silva and Rabelo 1997, Puigserver et al. 1998). An increased norepinephrine concentration in the blood increases the production of cyclic AMP (cAMP), lipolysis and free fatty acids (FFA) in adipose tissue. Free fatty acids in mitochondria become a substrate for thermogenesis, being a factor that controls the activity of UCP1s. Excess lipids material is transported in the form of lipoproteins to the liver, which plays an important role in the thermoregulation mechanism. (Siemińska 2007, Stocks et al. 2004). Bartelt et al. (2011) when investigating whether cold exposure alters the lipoprotein profile of mice kept at $4{ }^{\circ} \mathrm{C}$ in a cold room, have observed that triglyceride-rich lipoprotein (TRL) concentrations are markedly reduced after $4 \mathrm{~h}$ and $24 \mathrm{~h}$ with slightly increased HDL concentration, which is probably explained by an increase of TRL-derived HDL precursors. Moreover, they have found that endothelial permeability in BAT is increased upon cold exposure and that this process depends on simultaneous lipolysis. These findings indicate that a cold exposureinduced increase in lipoprotein turnover remodels endothelial permeability, thereby allowing an increased internalization of TRLs into BAT. Taken together, activated BAT accelerates plasma TRL turnover and is a major target organ for TRL uptake. Based on their findings, these authors have concluded that modulation of BAT activity can correct hyperlipidaemia (Bartelt et al. 2011).

The obtained results confirm the postulate of whole-body cryostimulation interventions capability in the regulation of lipid metabolism. We are aware of the limitations of the study. Therefore, the study was not performed in patients with dyslipidemia, and the next stage of research should attempt to apply this form of its physical effects in the prevention and reduction of risk of cardiovascular diseases in patients with dyslipidemia and metabolic syndrome, taking into account contraindications to therapy.

\section{Conflict of Interest}

There is no conflict of interest.

\section{Acknowledgements}

This work was supported by the National Science Centre grant No: N-N404-312940 and by Pomeranian Medical University in Szczecin. 


\section{References}

BANFI G, LOMBARDI G, COLOMBINI A, MELEGATI G: Whole-body cryotherapy in athletes. Sports Med 40: 509-517, 2010.

BANFI G, MELEGATI G, BARASSI A, MELZID'ERIL G: Beneficial effect of the whole-body cryotherapy on sport hemolysis. JHSE 4: 189-193, 2009b.

BANFI G, MELEGATI G, BARASSI A, MELZID'ERIL AG: Effects of the whole-body cryotherapy on NTproBNP, hsCRP and troponin I in athletes. $J$ Sci Med Sport 12: 609-610, 2009a.

BARTELT A, BRUNS OT, REIMER R, HOHENBERG H, ITTRICH H, PELDSCHUS K, KAUL MG, TROMSDORF UI, WELLER H, WAURISCH C, EYCHMÜLLER A, GORDTSPL, RINNINGER F, BRUEGELMANN K, FREUND B, NIELSEN P, MERKEL M, HEEREN J: Brown adipose tissue activity controls triglyceride clearance. Nat Med 17: 200-205, 2011.

BROJEK W, WARZOCHA A: Cryotherapy - answers to frequently asked questions. (In Polish) Acta Bio Optica Inform Med 12: 108-109, 2006.

CANNON B, NEEDERGAARD J: Brown adipose tissues function and physiological significance. Physiol Rev 84: 277-359, 2004.

CASTELLANI JW, YOUNG AJ: Human physiological responses to cold exposure: Acute responses and acclimatization to prolonged exposure. Auton Neurosci 196: 63-74, 2016.

CHOLEWKA A, STANEK A, SIEROO A, DRZAZGA Z: Thermographs study of skin response due to whole-body cryotherapy. Skin Res Technol 18: 180-187, 2011.

CHUDECKA M, LUBKOWSKA A, KLIMEK A, SZYGUŁA Z: The impact of systemic cryotherapy on the distribution and the dynamics of temperature changes in the selected parts of body. (In Polish) Acta Bio Optica Inform Med 14: 129-132, 2008.

CHUDECKA M, ZABORSKI D, LUBKOWSKA A, GRZESIAK W, KLIMEK A, MODRZEJEWSKI A: Temperature changes in selected areas of body surface induced by systemic cryostimulation. Aviat Space Environ Med 85: 1170-1176, 2014.

CIACH E, BOBILEWICZ D, KMIN E: Cholesterol LDL - direct measurements and calculated from Friedewald formula. J Lab Diagn 47: 419-423, 2011.

DĘBIEC-BĄK A, SKRZEK A, PODBIELSKA H: Application of thermovision for estimation of the optimal and safe parameters of the whole body cryotherapy. J Therm Anal Calorim 111: 1853-1859, 2013.

DULIAN K, LASKOWSKI R, GRZYWACZ T, KUJACH S, FLIS DJ, SMARUJ M: The whole body cryostimulation modifies irisin concentration and reduces inflammation in middle aged, obese men. Cryobiology 71: 398-404, 2015.

FERRARO GA, DE FRANCESCO F, CATALDO C, ROSSANO F, NICOLETTI G, D'ANDREA F: Synergistic effects of cryolipolysis and shock waves for noninvasive body contouring. Aesth Plast Surg 36: 666-679, 2012.

FUJITA J: Cold shock response in mammalian cells. J Mol Microbiol Biotechnol 1: 243-255, 1999.

HAMAN F, PERONNET F, KENNY GP, MASSICOTTE D, LAVOIE C, SCOTT C, WEBER JM: Effect of cold exposure on fuel utilization in humans: plasma glucose, muscle glycogen and lipids. $J$ Appl Physiol 93: 77-84, 2002.

HASSI J, HOLMÉR I, RINTAMÄKI H: Health and performance in the cold. Int J Circumpolar Health 60: 411-412, 2001.

HAUSSWIRTH C, SCHAAL K, LE MEUR Y, BIEUZEN F, FILLIARD JR, VOLONDAT M, LOUIS J: Parasympathetic activity and blood catecholamine responses following a single partial-body cryostimulation and a whole-body cryostimulation. PLoS One 8: e72658, 2013.

HERMAN JP, MCKLVEEN JM, GHOSAL S, KOPP B, WULSIN A, MAKINSON R, SCHEIMANN J, MYERS B: Regulation of the hypothalamic-pituitary-adrenocortical stress response. Compr Physiol 6: 603-621, 2016.

HIRAMATSU K, YAMADA T, KATAKURA M: Acute effects of cold on blood pressure, renin-angiotensinaldosterone system, catecholamines and adrenal steroids in man. Clin Exp Pharmacol Physiol 11: 171-179, 1984. 
IRELAND HE, LEONI F, ALTAIE O, BIRCH CS, COLEMAN RC, HUNTER-LAVIN C, WILLIAMS JH: Measuring the secretion of heat shock proteins from cells. Methods 43: 176-183, 2007.

JÄÄTTELÄ M: Heat shock proteins as cellular lifeguards. Ann Med 31: 261-271, 1999.

KARMOWSKI A, SOBIECH KA, MARKUSZEWSKI M, MAJDA J, ŁĄTKOWSKI K, KARMOWSKI M: Values of the lipid indexes in monitoring of the hormone replacement therapy in the postmenopausal women. Adv Clin Exp Med 14: 725-729, 2005.

KEPINSKA M, GDULA-ARGASINSKA J, DABROWSKI Z, SZAREK M, PILCH W, KRESKA-KORUS A, SZYGULA Z: Fatty acids composition in erythrocyte membranes of athletes after one and after a series of whole body cryostimulation sessions. Cryobiology 74: 121-125, 2017.

KLEIN KB, ZELICKSON B, RIOPELLE JG, OKAMOTO E, BACHELOR EP, HARRY RS, PRECIADO JA: Non-invasive cryolipolysis ${ }^{\mathrm{TM}}$ for subcutaneous fat reduction does not affect serum lipid levels or liver function tests. Laser Surg Med 41: 785-790, 2009.

KRAUS WE, HOUMARD JA, DUSCHA BD, KNETZGER KJ, WHARTON MB, MCCARTNEY JS, BALES CW, HENES S, SAMSA GP, OTVOS JD, KULKARNI KR, SLENTZ CA: Effects of the amount and intensity of exercise on plasma lipoproteins. N Engl J Med 347: 1483-1492, 2002.

KREGEL KC, SEALS DR, CALLISTER R: Sympathetic nervous system activity during skin cooling in humans: relationship to stimulus intensity and pain sensation. J Physiol 454: 359-371, 1992.

KREGEL KC: Heat shock proteins: modifying factors in physiological stress responses and acquired thermotolerance. J Appl Physiol 92: 2177-2186, 2002.

LEPPÄLUOTO J, LYBECK H, VIRKKUNEN P, PARTANEN J, RANTA T: Effects of immersion in cold water on the plasma ACTH, GH, LH and TSH concentrations in man. In: Circumpolar Health 81. HARVALD B, HJ HART HJ (eds), Stougaard Jensen, Copenhagen, 1981, pp 601-602.

LEPPÄLUOTO J, PÄÄKKÖNEN T, KORHONEN I, HASSI J: Pituitary and autonomic responses to cold exposures in man. Acta Physiol Scand 84: 255-264, 2005.

LUBKOWSKA A, BANFI G, DOŁĘGOWSKA B, D'ERIL BV, ŁUCZAK J, BARASSI A: Changes in lipid profile in response to three different protocols of whole-body cryostimulation treatments. Cryobiology 61: 22-26, 2010c.

LUBKOWSKA A, CHUDECKA M, KLIMEK A, SZYGUŁA Z, FRĄCZEK B: Acute effect of a single whole-body cryostimulation on prooxidant-antioxidant balance in blood of healthy young men. $J$ Therm Biol 33: 464-467, 2008.

LUBKOWSKA A, DOŁĘGOWSKA B, SZYGUŁA Z, KLIMEK A: The activity of selected enzymes in erythrocytes and the level of plasma antioxidants in response to single whole-body cryostimulation in humans. Scand J Lab Clin Invest 69: 387-394, 2009.

LUBKOWSKA A, SUSKA M: The increase in systolic and diastolic blood pressure after exposure to cryogenic temperatures in normotensive men as a contraindication for whole-body cryostimulation. $J$ Therm Biol 36: 264-268, 2011.

LUBKOWSKA A, SZYGUŁA Z, KLIMEK AJ, TORII M: Do sessions of cryostimulation have influence on white blood cell count, level of IL6 and total oxidative and antioxidative status in healthy men? Eur J Appl Physiol 109: 67-72, $2010 \mathrm{~b}$.

LUBKOWSKA A, SZYGUŁA Z: Changes in blood pressure with compensatory heart rate decrease and in the level of aerobic capacity in response to repeated whole-body cryostimulation in normotensive, young and physically active men. Int J Occup Med Environ Health 23: 367-375, 2010a.

MATZ JM, BLAKE MJ, TATELMAN HM, LAVOI KP, HOLBROOK NJ: Characterization and regulation of coldinduced heat shock protein expression in mouse brown adipose tissue. Am J Physiol 269: R38-R47, 1995.

POURNOT H, BIEUZEN F, LOUIS J, FILLARD J-R, BARBICHE E, HAUSSWIRTH C: Time-course of changes in inflammatory response after whole-body cryotherapy multi exposures following severe exercise. PLoS One 6: e22748, 2011.

PUIGSERVER P, WU Z, PARK CW, GRAVES R, WRIGHT M, SPIEGELMAN BM: A cold-inducible coactivator of nuclear receptors linked to adaptive thermogenesis. Cell 92: 829-839, 1998.

SAMEC S, SEYDOUX J, DULLO AG: Role of UCP homologues in skeletal muscles and brown adipose tissue: mediators of thermogenesis or regulators of lipids as fuel substrate? FASEB J 12: 715-724, 1998. 
SELFE J, ALEXANDER J, COSTELLO JT, MAY K, GARRATT N, ATKINS S, DILLON S, HURST H, DAVISON M, PRZYBYLA D, COLEY A, BITCON M, LITTLER G, RICHARDS J: The effect of three different $\left(-135^{\circ} \mathrm{C}\right)$ whole body cryotherapy exposure durations on elite rugby league players. PLoS One 9: e86420, 2014.

SIEMIŃSKA L: Adipose tissue. Pathophysiology, distribution, sex differences and the role in inflammation and cancerogenesis. (In Polish) Endokrynol Pol 58: 330-342, 2007.

SILVA JE, RABELO R: Regulation of the uncoupling protein gene expression. Eur J Endocrinol 136: 251-264, 1997.

SINGH I, SHISHEHBOR M, ANSELL B: High-density lipoprotein as a therapeutic target - a systematic review. JAMA 298: 786-798, 2007.

SKRZEP-POLOCZEK B, ROMUK E, BIRKNER E, WIŚNIOWSKA B, BECK B, JAGODZIŃSKI L: The effect of whole-body cryotherapy on lipids parameters in experimental rat model. Pol Balneol 44: 7-13, 2002.

SMITH SM, VALE WW: The role of the hypothalamic-pituitary-adrenal axis in neuroendocrine responses to stress. Dialogues Clin Neurosci 8: 383-395, 2006.

SMOLANDER J, LEPPÄLUOTO J, WESTERLUND T, OKSA J, DUGUE B, MIKKELSSON M, RUOKONEN A: Effects of repeated whole-body cold exposures on serum concentrations of growth hormone, thyrotropin, prolactin and thyroid hormones in healthy women. Cryobiology 58: 275-278, 2009.

SPIEGELMAN BM, FLIER JS: Obesity and the regulation of energy balance. Cell 104: 531-554, 2001.

STOCKS JM, TAYLOR NAS, TIPTON MJ, GREENLEAF JE: Human physiological responses to cold exposure. ASEM 75: 444-457, 2004.

SUSZKO R: Whole body cryotherapy. Med Rehab 7: 63-71, 2003.

SZYGUŁA Z, LUBKOWSKA A, GIEMZA C, SKRZEK A, BRYCZKOWSKA I, DOŁĘGOWSKA B: Hematological parameters, and hematopoietic growth factors: Epo and IL-3 in response to whole-body cryostimulation (WBC) in military academy students. PLoS One 9: e93096, 2014.

VALLERAND AL, JACOBS I: Energy metabolism during cold exposure. J Sports Med 3 (Suppl 1): S191-S193, 1992.

VALLERAND AL, LUPIEN J, BUKOWIECKI LJ: Cold exposure reverses the diabetogenic effects of high-fat feeding. Diabetes 35: 329-334, 1986.

WOŹNIAK A, WOŹNIAK B, DREWA G, MILA-KIERZENKOWSKA C, RAKOWSKI A: The effect of whole-body cryostimulation on lysosomal enzyme activity in kayakers during training. Eur J Appl Physiol 100: 137-142, 2007.

ZALEWSKI P, BUSZKO K, ZAWDKA-KUNIKOWSKA M, SŁOMKO J, SZRAJDA J, KLAWE JJ, TAFIL-KLAWE M, SINSKI M, NEWTON J: Cardiovascular and autonomic responses to whole-body cryostimulation in essential hypertension. Cryobiology 69: 249-255, 2014. 